\title{
Potential of the renewable energy development in Jammu and Kashmir, India
}

\author{
Arsalan Nisar , Carlos Rodríguez Monroy
}

\begin{abstract}
A B S T R A C T
The future economic growth for India is likely to result in rapid and accelerated surge in energy demand, with expected shortages in terms of supply. Many of its current policies and strategies are aimed at the improvement and possible maximization of energy production from the renewable sector. It is also clear that while energy conservation and energy efficiency can make an important contribution, renewable energies will be essential to the solution and are likely to play an increasingly important role for providing enhanced energy access, reducing consumption of fossil fuels, and helping India pursue its low-carbon progressive pathway. However, most of the states in India, like the northernmost state of Jammu and Kashmir, have experienced an energy crisis over a sustained period of time and the government both at center and state level has to embark upon with these pressing issues in a more sustainable manner and accordingly initiate various renewable energy projects within these states. This paper will provide a broad-spectrum view about the energy situation within Jammu and Kashmir and will highlight the current policies along with future strategies for the optimal utilization of renewable energy resources.
\end{abstract}

\section{Contents}

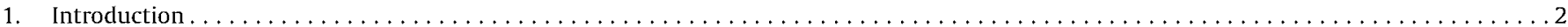

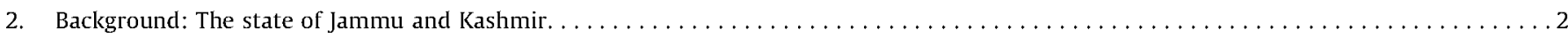

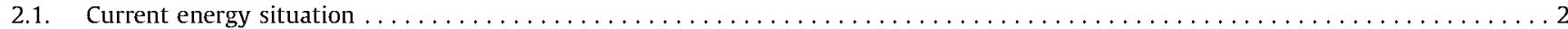

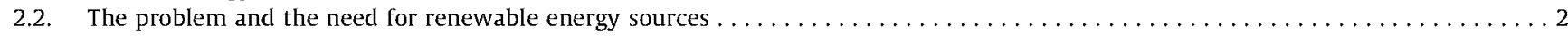

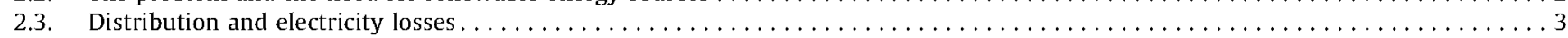

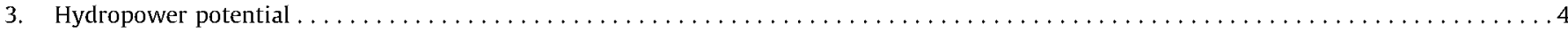

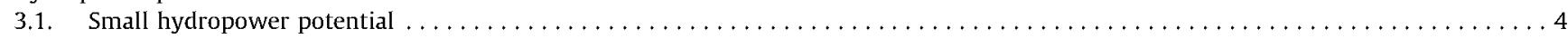

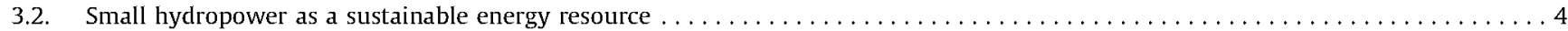

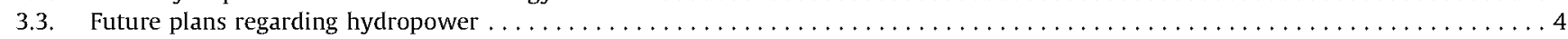

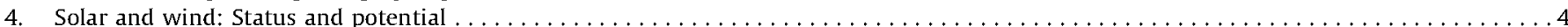

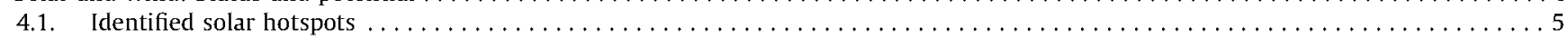

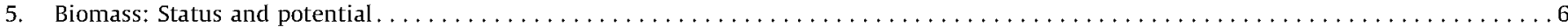

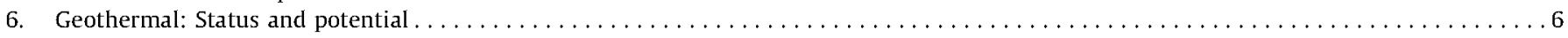

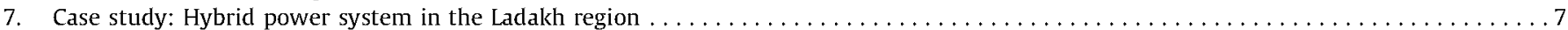

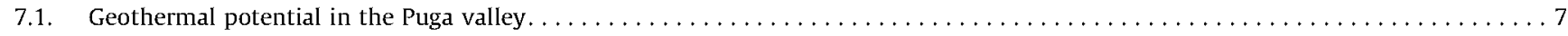

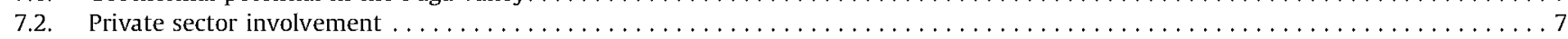

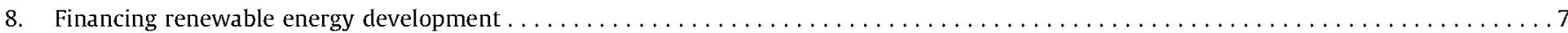

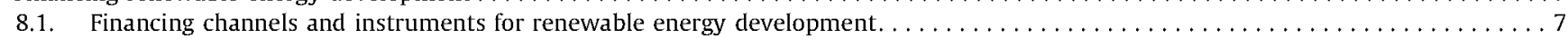

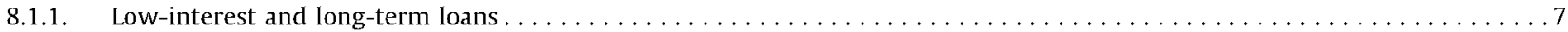

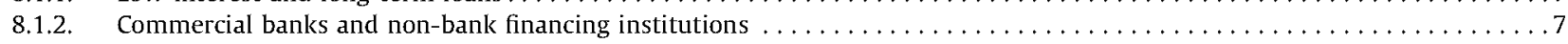

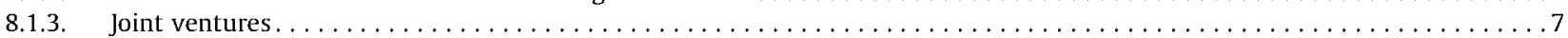

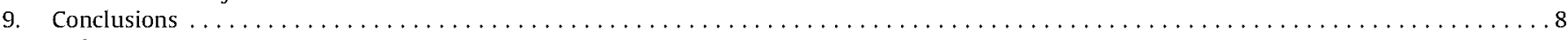

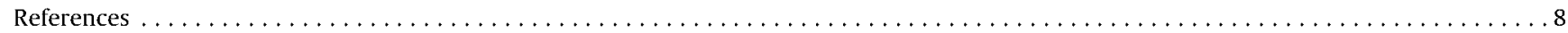




\section{Introduction}

India is currently experiencing the much-needed low-carbon transition and with the second highest population in the world combined with a positive Gross Domestic Growth (GDP) growth rate of around $8 \%$, the demand for energy is ever increasing. There is a need to address the future energy security of supply of India in a sustainable manner and this requires greater need to develop and harness the vast renewable energy potential. Renewable energy (RE) will be an important part of India's plan to add new capacity and also increase energy security, address environmental concerns, and lead the massive market for RE.

However, renewable energy development has been underused and lacks an integrated national economic perspective. This has largely been driven by uncoordinated state policies and programs. Many of the states with the richest RE resources like the state of Jammu and Kashmir (J\&K) lag far behind in the utilization and development of renewable sources. India needs to address this uneven development across states and within the renewable energy sector. Moreover, this paper provides a framework that will help to understand the problems and limitations involved with the implementation of renewable energy policies in J\&K.

The paper is structured as: the next section will provide a brief introduction to J\&K along with the current energy situation and the potential for renewable energy sources. Section 3 provides an overview of the hydro potential in J\&K.

\section{Background: The state of Jammu and Kashmir}

J\&K is the northernmost state of the Union of India, lying between six mountain ranges and covering an area of 222,236 square kilometers. J\&K commonly known as Kashmir, shares a border with the Indian states of Himachal Pradesh and Punjab to the south and internationally with the People's Republic of China to the north and east and with the Pakistan-administered territories of Azad Kashmir and Gilgit-Baltistan, to the west and northwest, respectively. The state accounts for $3.2 \%$ of the total geographic area of India and $1 \%$ of its total population. J\&K consists of three territorial divisions: Jammu, Kashmir valley and Ladakh, and is further divided into 22 administrative districts (Fig. 1) [1].

\subsection{Current energy situation}

$\mathrm{J} \& \mathrm{~K}$ is one of the energy-starved states within India and the inadequacy of the existing power capacity power has been affecting the pace of development in all sectors of the economy. The state has a unique position in the power generation and power market within northern India. Historically the principal energy source in J\&K has been hydroelectricity and still constitutes around $68 \%$ of the total energy mix. Its rivers, which are the main source of power generation, have the maximum flow during the summer season (April-October) and thus have a potential to meet the pressing energy demands. However, during the rest of the year, i.e., in the winter season, the water level drops to one third of the annual average and the demand increases due to the extra usage of electricity for heating and lighting purpose and thus resulting in purchase of large quantities of power from adjacent states. This has placed the state finances in a deficit situation. During the fiscal year 2008-2009 alone, only 29\% of the power was produced within the state, while the rest was purchased, thus creating large differences in revenue and income. The figures for the last ten years indicate that energy poverty has created a lot of pressure on the limited forest reserves and the state government has been forced to buy energy resources to meet the demand during the winter season, when the gap between demand and supply is highest.

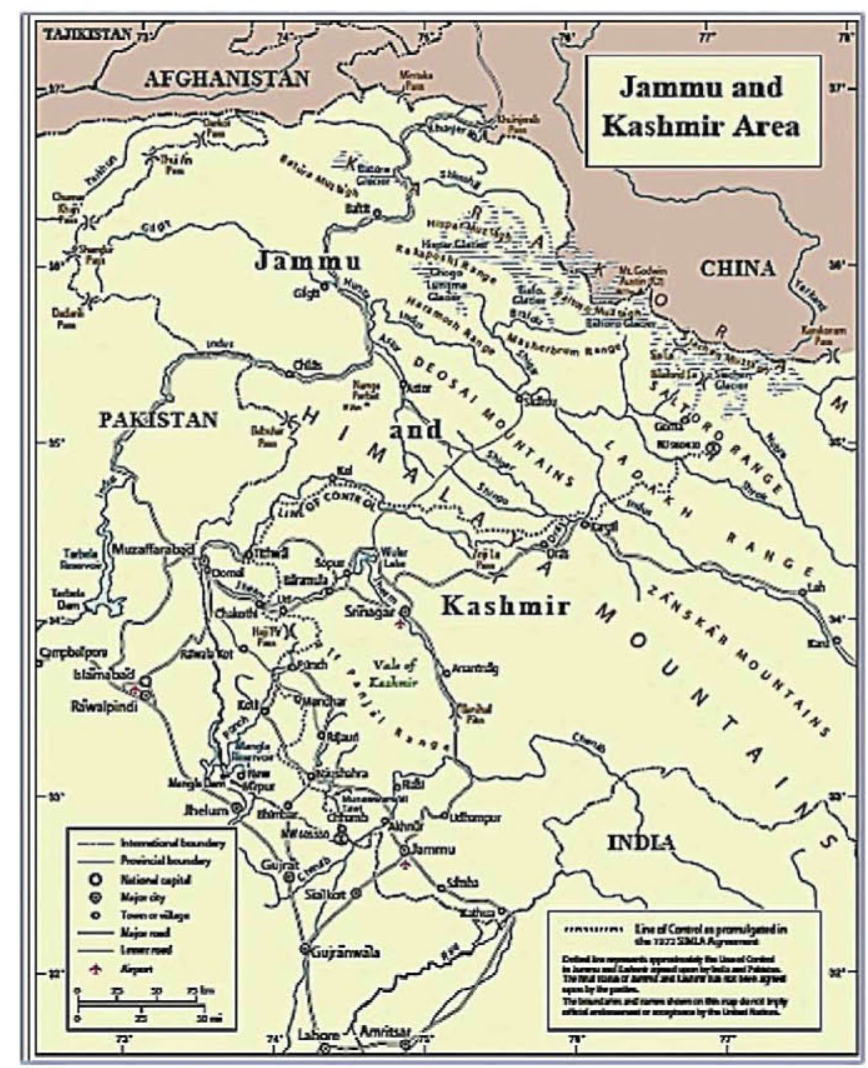

GDP (2008): $\$ 7.6$ bn

GDP per person (2008): \$ 1847 (PPP adjusted)

GDP per person (2008): $\$ 678$ (Nominal)

Population (2008): $11.2 \mathrm{~m}$

Source: The Economist Intelligence Unit; CEIC; national statistics [15]

Fig. 1. Map of Jammu and Kashmir according to the United Nations (UN). Source: United Nations, 2011 [14] The Economist Intelligence Unit; CEIC; national statistics [15].

\section{Table 1}

Installed power capacity in Jammu and Kashmir by the end of 2009. Source: Ministry of Power, Govt. of India [7].

\begin{tabular}{lllllll}
\hline $\begin{array}{l}\text { Nuclear } \\
(\mathrm{MW})\end{array}$ & $\begin{array}{l}\text { Hydro } \\
(\mathrm{MW})\end{array}$ & $\begin{array}{l}\text { Other } \\
\text { Renewables } \\
(\mathrm{MW})\end{array}$ & $\begin{array}{l}\text { Diesel } \\
(\mathrm{MW})\end{array}$ & $\begin{array}{l}\text { Gas } \\
(\mathrm{MW})\end{array}$ & $\begin{array}{l}\text { Coal } \\
(\mathrm{MW})\end{array}$ & $\begin{array}{l}\text { Total } \\
(\mathbf{M W})\end{array}$ \\
\hline 68 & 1469 & 113 & 302 & 9 & 198 & $\mathbf{2 1 5 8}$ \\
\hline
\end{tabular}

From the year 1990 to 2005 , the energy demand in J\&K grew by $3.5 \%$ per year, but the state recorded a deficit of more than $20 \%$ in the availability of power during peak hours. This deficit is expected to increase in the future if major steps towards the development and exploitation of renewable resources are not taken. Hence, a strong need exists to design renewable energy models that can contribute towards solving the persistent energy problems in J\&K (see Tables 1 and 2) [1]. The next section will measure the persistent energy problems and highlight the need for renewable sources.

\subsection{The problem and the need for renewable energy sources}

$\mathrm{J} \& \mathrm{~K}$ has the legacy of state-owned vertically integrated electricity supply industries, often with lobbying of tariff setting that 
leads to excessively cheap electricity for domestic consumers, high levels of non-technical losses due to theft or failure to collect bills, high levels of debt or arrears, and poor commercial performance as a measure of ability to collect revenues to cover costs. As a result, it is difficult for the sector to finance its investment needs on commercial terms, and often suffers from poor maintenance with frequent equipment failures (e.g., as measured by transformer failures and low generation availability), with power shortages and frequent load shedding [27].

RE development is an important tool for stimulating regional economic growth, particularly for many of the underdeveloped states like J\&K. Moreover, it can provide secure electricity supply to foster domestic industrial advancement, attract new investments, and consequently serve as an important employment growth engine, generating additional income.Tables 3-5

Historically, J\&K has been primarily dependent on fossil fuels for its energy requirements and the exhaustible nature along with the volatile market prices of fossil fuels further contribute towards its energy insecurity. The state government needs to recognize the central role of energy and the need to have a set of policies that promote efficient use of conventional energies coupled with proactive realization of non-conventional energy resources and thus reduce greenhouse gas (GHG) emissions to achieve sustainable growth.

Over the recent years, J\&K has seen major progression in terms of renewable energy (RE) utilization driven by factors including emission reduction, security of energy supply and employment within a constraint of acceptable economic cost. It needs to

Table 2

Power demand and availability in Jammu and

Kashmir by the end of 2009 .

Source: JKSPDC, 2010 [28].

$\begin{array}{ll}\text { Unrestricted peak power demand (MW) } & 2120 \\ \text { Peak demand met (MW) } & 1458 \\ \text { Peak deficit (MW) } & 662 \\ \text { Peak deficit (\%) } & 31.23\end{array}$

Table 3

Area of barren or uncultivable land in Jammu and Kashmir of identified solar hotspots.

Source: Directorate of Economics and Statistics, Government of India [9].

\begin{tabular}{lll}
\hline Total area $(\mathbf{1 0 0 0}$ ha) & Barren or uncultivable land $(\mathbf{1 0 0 0}$ ha) & $\mathbf{( \% )}$ \\
\hline 3781 & 277 & 8 \\
\hline
\end{tabular}

Table 4

Biomass power estimation in J\&K by the end of year 2008 .

Source: MNRE [26].

\begin{tabular}{lllll}
\hline $\begin{array}{l}\text { Area } \\
(\mathbf{k H A})\end{array}$ & $\begin{array}{l}\text { Crop } \\
\text { production } \\
(\mathbf{k t} / \text { year) }\end{array}$ & $\begin{array}{l}\text { Biomass } \\
\text { generation } \\
(\mathbf{k t} / \text { year })\end{array}$ & $\begin{array}{l}\text { Biomass } \\
\text { surplus } \\
(\mathbf{k t} / \text { year })\end{array}$ & $\begin{array}{l}\text { Power } \\
\text { potential } \\
(\text { MWe })\end{array}$ \\
\hline 368 & 648 & 1198 & 237 & 32 \\
\hline
\end{tabular}

intensify the RE utilization by improving its policies and programs to attain greater energy accessibility. Similar policies and programs are enhancing the role of renewable energies in many economies like that of New Zealand [2]Fig. 2.

\subsection{Distribution and electricity losses}

Distribution is the weakest link of J\&K's power supply chain as it faces substantial technical losses (because of overloading of

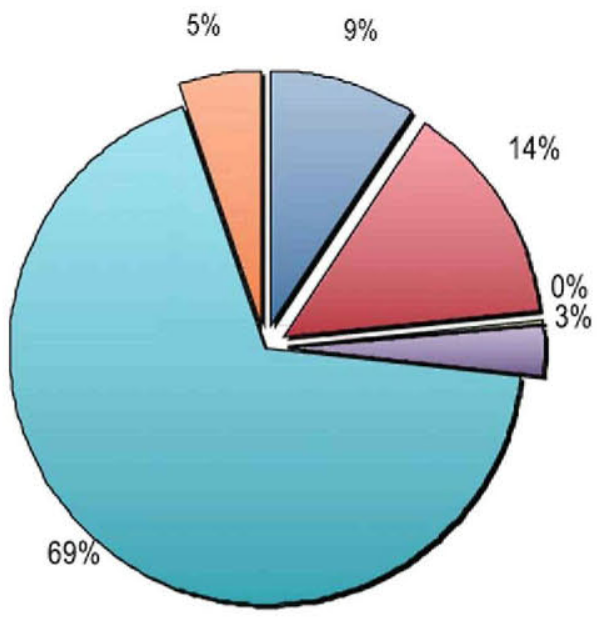

- Coal

- Diesel

- Gas

- Nuclear

Hydro

Other Renewable

Fig. 2. The current energy mix for Jammu and Kashmir by the end of 2009. Source: Ministry of Power, Government of India (2009) [7]

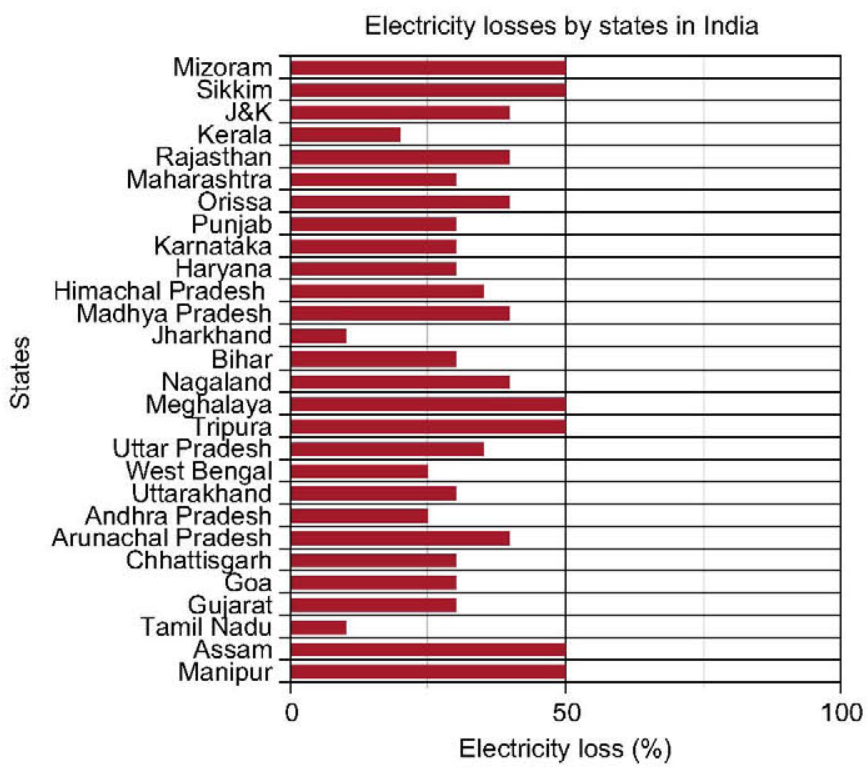

Fig. 3. Electricity losses by states. The boundaries and names shown and the designations used on maps included in this publication do not imply official endorsement or acceptance by the IEA.

Source: IEA, 2007 [3].

Table 5

IREDA subsidy schemes available for small hydropower development.

Source: IREDA 2011 [25].

\begin{tabular}{lll}
\hline Scheme areas & Upto $\mathbf{1 0 0}$ KW & From 101 to 999 KW \\
\hline J\&K, Sikkim, Himachal Pradesh, & $\begin{array}{l}\text { 45\% of the project cost limited } \\
\text { to Rs. 30,000/- per kW* }\end{array}$ & $\begin{array}{l}\text { 45\% of the project cost limited } \\
\text { to Rs. 3000,000+Rs. 21,625 per kW }\end{array}$ \\
\hline
\end{tabular}

* Rupees (Rs.) 1 USD $=44.43$ rupees as on 21.07.11, courtesy: Reserve Bank of India. 
transformers and distribution lines, for instance) and commercial losses of electricity (because of low metering efficiency, poor billing and collection and large-scale theft of power) averaging $40 \%-50 \%$ of total generation in 2006/07 and amongst the highest in India, as illustrated in Fig. 3. The electricity losses in India are among the highest in the world and consequently compromise the financial viability of the power sector, and discourage private investment [3].

\section{Hydropower potential}

J\&K has a hydropower potential of the order of $20,000 \mathrm{MW}$ of which about $16,000 \mathrm{MW}$ have been identified, and a mere $12 \%$ i.e., about $2400 \mathrm{MW}$ have been harnessed so far and $900 \mathrm{MW}$ are under construction. Fig. 4 depicts the basin-wide identified and harnessed potential. Ironically, this huge hydropower potential has not been fully exploited due to the shortage of financial resources and also as a consequence of the provisions in accordance to the Indus Water Treaty signed between India and Pakistan. The Indus basin runs through both India and Pakistan and comprises three western rivers: the Indus, the Jhelum and Chenab and three eastern rivers: the Sutlej, the Beas and the Ravi. The treaty restrains the right of J\&K on the upper Chenab, Jhelum, and Indus for purposes of consumptive hydroelectric storage and diversions within these basins [34]. However, the Government of Jammu and Kashmir (GOJK) has decided to encourage generation of power through small hydropower sources of energy and has framed a policy so that the development of this sector serves as a driving factor to achieve the objective of promoting the all-round development of the region $[28,1]$.

\subsection{Small hydropower potential}

Small hydropower (SHP) - one of the least expensive and most efficient forms of RE - lies largely untapped in J\&K. It is an attractive $\mathrm{RE}$ source as it uses mature and largely indigenous technology. SHP projects are appropriate for providing electricity to many of the remote and rural areas in India. India has an estimated small hydropower potential of about $15 \mathrm{GW}$, of which only about $2.5 \mathrm{GW}$ has been developed. Development has been relatively slow because of long delays in getting clearances and acquiring access to evacuation infrastructure, lack of clear policies for private sector participation, and issues associated with land acquisition. Rich north and northeastern states have lagged in tapping this resource. With their perennial Himalayan rivers,
Himachal Pradesh, J\&K, and Uttarakhand have 65\% of India's small hydropower resources and among the lowest generation costs. Despite these advantages, resource utilization remains low and raising the utilization rate requires immediate attention [4].

\subsection{Small hydropower as a sustainable energy resource}

SHP projects can be installed in rivers, small streams, dams and canals with low or negligible apparent environmental effects. In order to minimize the environmental effects and maximize water conservation, the Ministry of New and Renewable Energies (MNRE) has given prominence to the development and integration of SHP projects into river systems during the last few years $[21,22]$.

$\mathrm{J} \& \mathrm{~K}$ is one of the 14 Himalayan states that have a combined small hydropower potential of around $7550 \mathrm{MW}$. The Himalayan states are the most suitable for the development of small hydropower within India. Fig. 5 indicates the 246 small hydropower sites with a capacity of around $1141 \mathrm{MW}$ that have already been identified in J\&K by the Ministry of New and Renewable Energy (MNRE) [23].

J\&K is planning to increase its power generation from SHP by increasing the current 32 installed SHP projects (113 MW, 8\% installed capacity, with a Cost of Generation (CoG) of 3.92 rupees/ $\mathrm{kWh}$ ) to 37 in the near future to add around $6 \mathrm{MW}$ in capacity.

\subsection{Future plans regarding hydropower}

J\&K is planning to develop some 310 hydropower projects in order to meet the region's growing power requirements over the next two decades. The above-mentioned hydro potential is estimated at about 20,000 MW. 64 of the 310 projects will be developed in the first phase of the initiative. Power projects with capacity above $200 \mathrm{MW}$ are being assigned to the state-run National Hydroelectric Power Corp (NHPC), while mini-hydropower projects are going to be developed through institutional power promoters and local companies. Another part of the initiative to increase hydropower capacity is to turn towards more energy-efficient processes, which will also help the state to conserve electricity $[1,26]$.

\section{Solar and wind: Status and potential}

In 2009, India launched an ambitious plan to become a global leader in solar energy by introducing the Jawaharlal Nehru National Solar Mission (JNNSM) and plans to greatly increase its installed, grid-connected solar capacity by the end of 2022 .

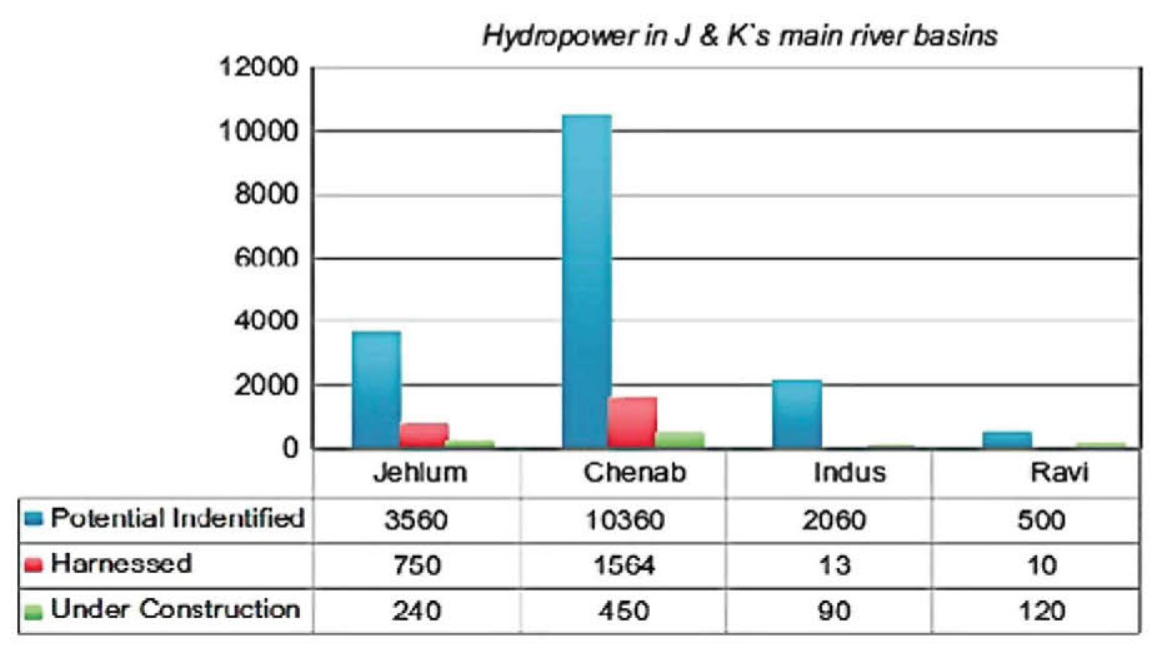

Fig. 4. Hydropower (MWs) in J\&Ks main river basins.Adapted by authors. Source: JKSPDC, 2010 [28]. 


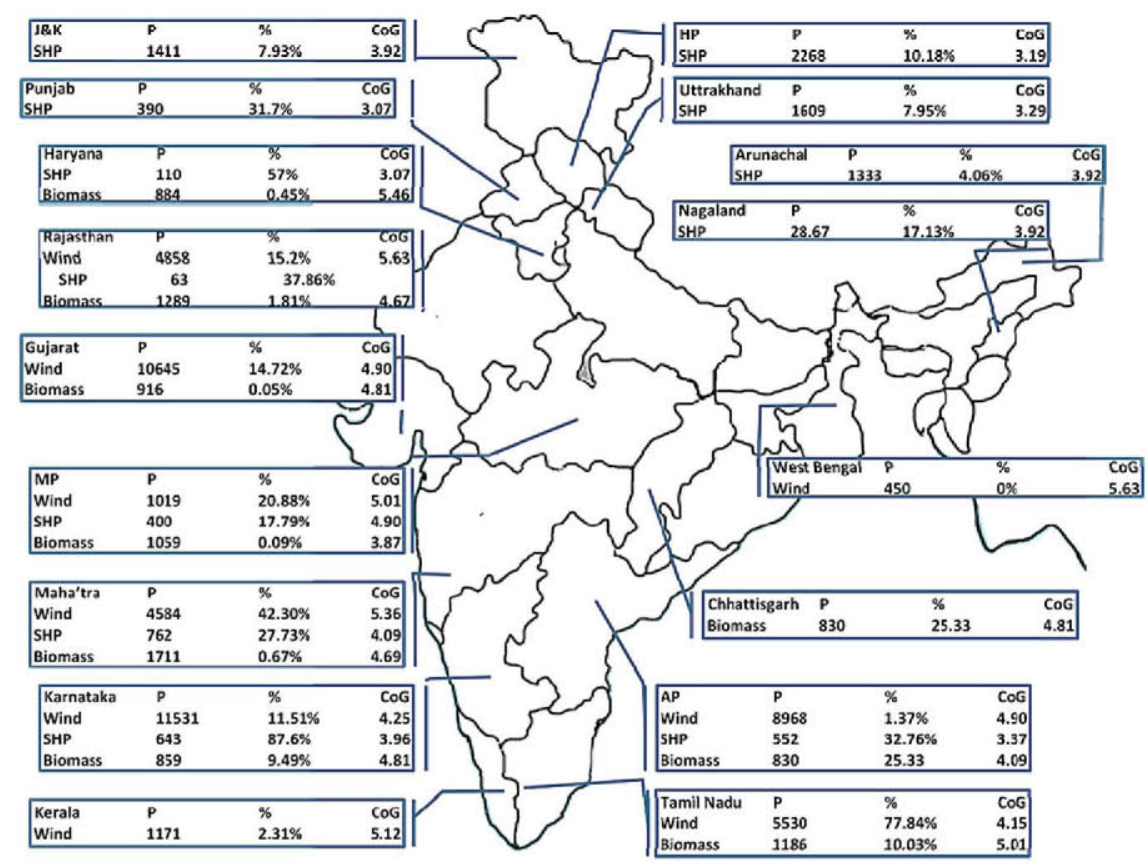

Fig. 5. Potential capacity (P), installed capacity (I), and economic cost of generation in rupees/kW h (CoG) of renewable energy sources, by state as of fiscal year 2009-2010. Yearly average 100 rupees/1US\$ exchange rate: 2.09 in 2010, 1.96 in 2009 [35].

Source: MNRE, Govt. of India [5].

The JNNSM has set its target of adding 1000 MW of capacity between 2010 and 2013. It seeks to increase the combined solar capacity to $20,000 \mathrm{MW}$ by end of 2022 [4].

As a result, the state government of J\&K introduced the 'Solar Power Policy-2010' with the following main objectives:

- To promote generation of green and clean power in J\&K using solar energy.

- To put in place an appropriate investment procedure that could leverage the Clean Development Mechanisms (CDM).

- To promote R\&D in order to facilitate technology transfer.

In addition, REEEP (Renewable Energy and Energy Efficiency Partnership) in association with the IFE (Institute of Energy Technology) of Norway is working closely with MNRE (Ministry of Renewable Energy, India) to promote RE in the form of solar energy, particularly addressing rural energy deployment in India. Many villages in J\&K are on the agenda along with other states of Madhya Pradesh, Jharkhand, etc. $[11,12]$. The New and Renewable Energy Ministry of India has estimated the solar energy potential at 20,000 MW by the year 2020 . Most of the solar potential lies in the northeastern area of Ladakh.

Furthermore to solar power as a potential source of RE, wind energy is practically untapped as a major RE resource and thus venturing into this would be beneficial for the existing and future energy demand. Recently, the Ministry of New and Renewable Energy (MNRE) has devised plans for bringing RE projects to the state with a strong focus on wind energy. The Central Electricity Regulatory Commission (CERC) lately passed new regulations, encouraging stronger participation from the private sector and inviting greater Foreign Direct Investment (FDI) by providing higher return on investments and other relevant incentives. These new initiatives will strongly benefit the state of $\mathrm{J} \& \mathrm{~K}$, as it presents itself with considerable potential for wind energy $[10,1]$.

\subsection{Identified solar hotspots}

Solar hotspots are the areas characterized by an exceptional solar power potential suitable for decentralized commercial

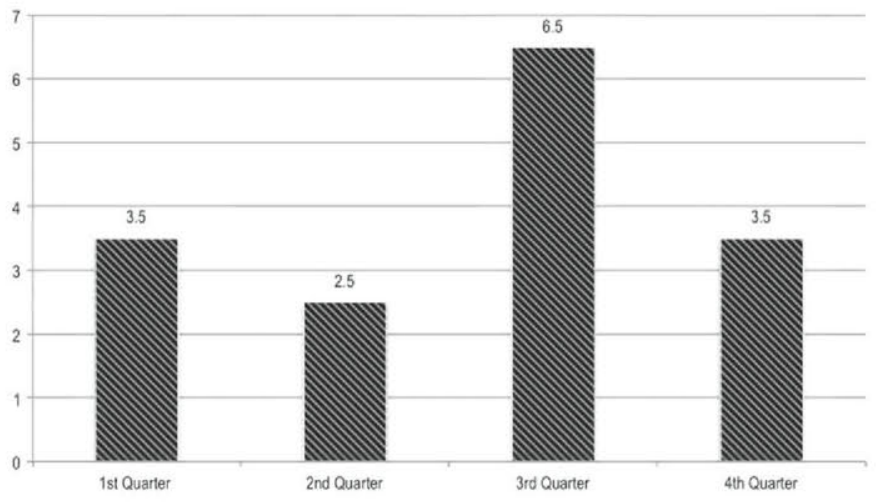

Fig. 6. Quarterly average insolation for $J \& K\left(\mathrm{kWk} / \mathrm{m}^{2} / \mathrm{h}\right)(1 \mathrm{st}$ Quarter-January to March, 2nd Quarter-Apr to June, 3rd Quarter-July to September and 4th QuarterOctober to December).

Source: Authors adaptation [13].

exploitation of energy. Identification of solar hotspots in a vast geographical expanse with dense habitations helps to meet escalating power demand in a decentralized, efficient and sustainable manner. Major hotspots have been located in the western Himalayan region comprising of Himachal Pradesh, J\&K and Uttarakhand. Specifically, the Eastern part of Ladakh region (J\&K) and minor parts of Himachal Pradesh, Uttarakand and Sikkim which are located within the Himalayan belt receive annual Global insolation of above $5 \mathrm{~kW} \mathrm{~h} / \mathrm{m}^{2} /$ day. These regions with viable potential constitute solar hotspots covering nearly 1.89 million $\mathrm{km}^{2}(\sim 58 \%)$ of India with the favorable prospects for solar-based RE technologies. The true potential of these identified solar hotspots can be realized with the proper dissemination of technologies for large-scale power generation. The estimated annual globalization insolation for the Kashmir region is $4.9 \mathrm{~kW} \mathrm{~h} / \mathrm{m}^{2} /$ day a value close to countries like Spain and Australia which have invested considerably in solar energy [13].

Fig. 6 indicates the quarterly average insolation for $\mathrm{J} \& \mathrm{~K}$ as an approximate estimate based on the monthly insolation in a year. 


\section{Biomass: Status and potential}

The worldwide application of biomass-based RE has been developing rapidly, in part because of its potential to address four common policy objectives - carbon emission reduction, energy security, regional employment, and environmental conservation.

Biomass has a huge potential in an agrarian economy like India. Like small hydropower, biomass remains largely underdeveloped in J\&K. According to the MNRE, J\&K has a biomass generation of $1198 \mathrm{kt}$ per year and this biomass could produce about 32 MWe of power. Despite these resources, the sector is the least developed with only about (less than 5\%) of potential realized to date.

According the World Bank, biomass is one of the most suitable options in terms of RE development in J\&K because of its two unique characteristics. The First, biomass plants require large quantities of fuel input for operations (biomass feedstock), which requires a well-developed supply chain. This disadvantage is also strength, because biomass is the only RE technology that can serve as a reliable alternative to diesel, which currently constitutes $14 \%$ of the energy mix in terms of power generation for J\& $\mathrm{K}$ (Fig. 2). However, the presence of multiple intermediaries, difficulties in administering and enforcing agricultural contracts, and the development of wastelands have led to underdeveloped fuel supply chains. Second, the sector suffers from lack of reliable resource assessment. The development of the biomass industry has been limited to only a few states, such as Andhra Pradesh and Tamil Nadu. Significant potential exists in economically underdeveloped states like J\&K and developing biomass is essential to reduce the electricity shortage and provide farmers with reliable additional sources of income [4].

Biomass can be converted into various bioenergy forms such as ethanol, butane, methane, hydrogen, electricity and biodiesel [30,31]. Some options are found to be very successful and efficient where as the other options are still facing technical challenges such as low energy net yield, water pollution, conversion efficiency, capital investment [32].

\section{Geothermal: Status and potential}

There is a need to consider the potential of geothermal resources in India and to harness these resources for power generation, space heating, greenhouse cultivation, and cooking. The Geological Survey of India estimates the potential to be of the order of $10,000 \mathrm{MW}$ produced from the 400 thermal springs distributed in different geographic and temperature zones. All the 400 thermal springs that have been mapped are accessible for utilization and if harnessed these springs can provide substantial energy in comparison to the current meager utilization of $200 \mathrm{MW}$. Out of the 400 thermal springs, 150 are present within the Himalayan Geothermal Belt (HGB) with temperature varying from 47 to $87^{\circ} \mathrm{C}$ (Fig. 7). The thermal provinces of Puga,

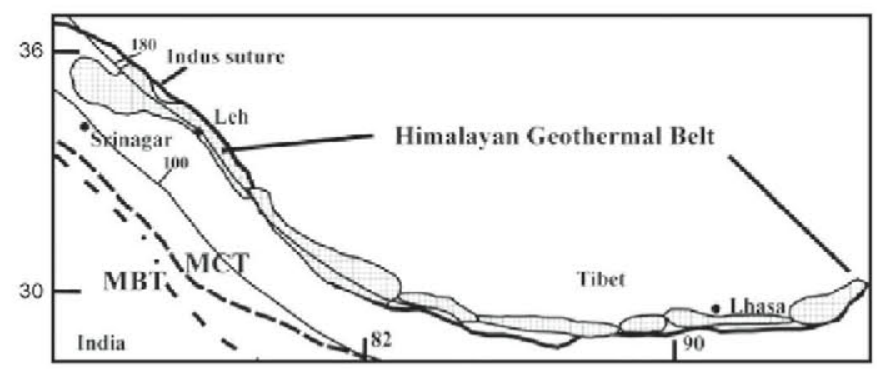

Fig. 7. Himalayan Geothermal Belt $(\mathrm{HGB})$ showing regional structure and heat flow values and highlighting the potential in Leh.

Source: Varun Chandrasekhar and Chandrasekharam, 2007 [33].

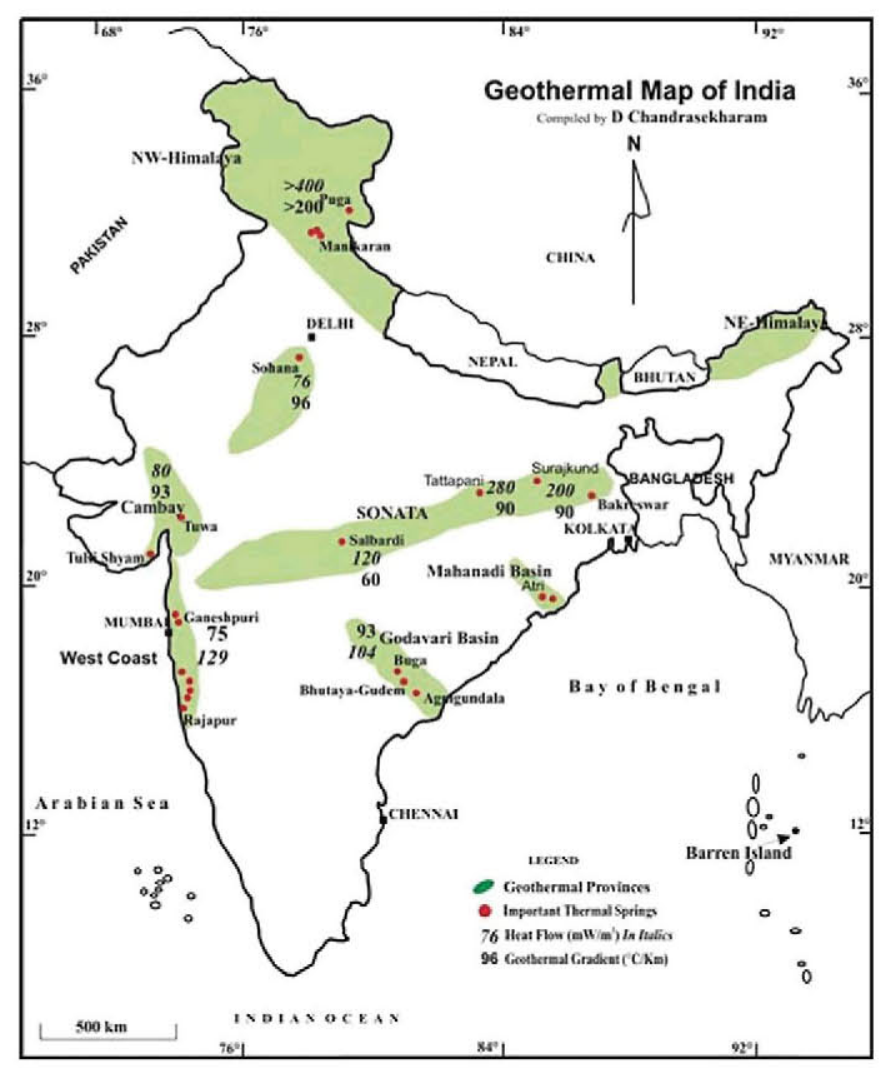

Fig. 8. Geothermal map of India indicating the geothermal potential in the Puga valley, J\&K [16].

Chumathang, Nubra located in proximity to Leh and Manikaran, and other thermal locations in Kulu valley fall within HGB.

Fig. 7 indicates the geothermal potential for India with considerable potential in the northeastern region of Ladakh. The Puga valley area is highlighted and has significant thermal springs that can be used for heating and for industrial purposes. Also demonstrations of various heat pumps are being carried out in the Puga valley and a $50 \mathrm{MW}$ plant is being planned Fig. 8.

Moreover, with the use of advanced drilling techniques and efficient heat exchangers, geothermal resources in the Ladakh region, besides generating power, can contribute significantly in mitigating Greenhouse Gas (GHG) emissions and earn substantial Certified Emission Rate (CER) ${ }^{1}$ see footnote income. In addition to the thermal springs, India has huge.

Enhanced Geothermal Systems (EGS) resources spread across all its states extending from the Himalayas to the southern part of the country. Chandrasekhar and Chandrasekharam [17] estimate EGS reserve made on a granite exposed area of $1000 \mathrm{~km}^{2}$ in the Ladakh region within the Himalayan geothermal belt is about $61,160 \times 10^{12} \mathrm{kWh}[16,17]$. Clean Development Mechanism (CDM) can be implemented in the Leh district of J\&K using geothermal energy and earn substantial savings through CER. Leh is located within the Himalayan Geothermal Belt (HGB), Puga and Chumathang geothermal fields, which has potential of generating $>250$ MWe from wet geothermal sources [18,17]. In addition to this, the EGS potential of the high heat generating

${ }^{1}$ A Kyoto Protocol unit equal to 1 metric tonne of $\mathrm{CO}_{2}$ equivalent. CERs are issued for emission reductions from Clean Development Mechanism (CDM) project activities. CDM is a mechanism under the Kyoto Protocol through which developed countries may finance greenhouse-gas emission reduction or removal projects in developing countries, and receive credits for doing so which they may apply towards meeting mandatory limits on their own emissions [6]. 
granites of HGB is about $1501 \times 10^{15} \mathrm{~kW} \mathrm{~h} \mathrm{[17].} \mathrm{By} \mathrm{implementing}$ CDM through geothermal energy sources, besides providing projected electricity demand to Leh ( $54 \mathrm{MWe}$ ) in the next decade, the region can save the currently retreating Gangotri glacier retreating at the rate of $18 \mathrm{~m}$ per year and help in preserving the Himalayan environmental ecosystem. In fact the HGB has the potential to generate surplus electricity through geothermal resources and make J\&K a zero electricity deficit state.

\section{Case study: Hybrid power system in the Ladakh region}

Ladakh is a remote province located in the Himalayan region with very low population density. It is the northeastern part of J\&K. Small-scattered loads and good availability of RE resources like hydro, solar, wind and geothermal makes the region ideal for RE based decentralized power generation. At present hydro and solar energy play an important role in power generation and rural electrification in Ladakh. Hydroelectricity from small hydroelectric plants (installed capacity $8.5 \mathrm{MW}$ ) accounts for about $60 \%$ of the total electricity generation. Currently, approximately 7000 solar photovoltaic (PV) domestic lighting systems provide electricity for lighting to about $25 \%$ of the households in Ladakh [13].

\subsection{Geothermal potential in the Puga valley}

The Puga geothermal field is located in the south-eastern part of Ladakh and has been recognized as the most intense geothermal field in India. At an altitude of about $4400 \mathrm{~m}$, it forms a part of the Himalayan geothermal belt (see Fig. 7). The Puga valley is surrounded by hills rising up to an altitude of about $6000 \mathrm{~m}$, forming the Puga region as a valley. The $15 \mathrm{~km}$ long and about $1 \mathrm{~km}$ wide valley trends nearly east-west in direction between Sumdo village in the east and Polokongka La in the west. This area, positioned just south to the Indus Suture Zone, has hot springs with surface flow temperatures up to $84.8^{\circ} \mathrm{C}$ (the boiling point of water at that altitude) [36]. Moreover, It is estimated to have the capacity to generate $30-40 \mathrm{MW}$ of electricity at a temperature of $240^{\circ} \mathrm{C}$ at relatively shallow depths [37].

\subsection{Private sector involvement}

In recognition of this geothermal potential, some private sector firms have shown great interest in utilizing this potential. In a major recent development, Thermax, an Indian capital goods manufacturer, will partner with Icelandic firm Reykjavík Geothermal to set up a geothermal power project in the Puga valley in Ladakh. Puga valley is known for high temperature geothermal systems, with the geothermal activity concentrated in a 3-sq. km area of the $15-\mathrm{km}$ long valley. It will be a pilot project in the order of $3 \mathrm{MW}$ and will be the first such project in India. The estimated potential for geothermal energy in India is about 10,000 MW and countries like Iceland, US and the Philippines are among the leaders in harnessing geothermal energy. Reykjavik Geothermal will help in drilling and exploration activities for the project. Also, a joint venture between Panax, an Australian firm, and Geosyndicate Power Private from India has been initiated to develop a $60 \mathrm{MW}$ project. These partnerships for the development of RE technology can significantly change the economic situation of the region [19].

\section{Financing renewable energy development}

The favorable regulatory, legislative and policy conditions are critical for financing renewable energy and these conditions can strongly affect the possibilities and competitiveness of RE in J\&K. The development of RE vastly depends on a variety of socio, techno, economic and institutional factors, but financing still remains as the most important factor. Appropriate financial incentives can speed up the development of RE. There is a need to discuss some of the broad issues involved in financing of $\mathrm{RE}$ within India and the consequent impact on Kashmir. The following section of the paper will present the different financing schemes that are established for the development of RE and highlight the main issues that persist [8].

\subsection{Financing channels and instruments for renewable energy development}

A number of financing instruments and channels are being used to develop the financing of renewable energies along with the implementation of RE technologies. The financing channels mainly include government finance, international funding, commercial banks and non-bank financial institutions, and private sector finance. An overview of the existing financing instruments to help promote investments in the development of $\mathrm{RE}$ is presented.

\subsubsection{Low-interest and long-term loans}

Indian Renewable Energy Development Agency (IREDA) provides low-interest loans to developers and entrepreneurs by means of innovative financing instruments. IREDA was established in 1987, under the administrative control of the Ministry of New and Renewable Energy (MNRE) to promote, develop and extend financial assistance for renewable energy and energy efficiency/conservation projects [25].

Loans are expected to progressively approach commercial market rates as the technologies gain wider acceptance and are considered more transparent and effective at reducing product costs than direct subsidies to provide low-interest financing to private entrepreneurs for relatively small RE projects $[25,8]$.

The table below presents the current IREDA subsidy schemes available for hydropower development in J\&K and in other states with considerable small hydropower potential.

\subsubsection{Commercial banks and non-bank financing institutions}

Internal financing will be a significant source of funding but in spite of a well-developed rural banking infrastructure, the links to the $\mathrm{RE}$ development remain insignificant. This is due to the high risk and lower returns associated with the RE loans and line of credits. The government needs to devise various financial instruments and insurance schemes that can lend security to private banks operating in rural areas in order to foster growth in the RE development. This model has seen some success in the rural health-financing sector within India.

\subsubsection{Joint ventures}

Recently J\&K has engaged in several successful joint ventures with companies nationally and internationally as well. For example, Power utility NHPC will invest around Rs. 2400 crores and help in setting up three projects in J\&K under a joint venture with J\&K state Power Development Corporation and PTC India. The joint venture entity named as, Chenab Valley Power Projects Pvt Ltd, will implement three projects having a total capacity of over 2100 MW. The three planned projects are Pakal Dul (1000 MW), Kiru (600 MW) and Kwar (520 MW). Also, Thermax, an Indian capital goods manufacturer, will partner with Icelandic firm Reykjavík Geothermal to set up a geothermal power project in the Puga valley in Ladakh. 


\section{Conclusions}

J\& K has a broad endowment of potential RE resources. It is one of the states that have the furthest to go in improving its energy efficiency. The sustainable solutions are offered by investing in the appropriate renewable energies in order to make J\&K energy independent. All the major RE sectors like solar, biomass, and small hydropower have considerable potential in resolving the energy requirements. However, in terms of infrastructure it suffers from lack of strong indigenous supply chains. Specifically, the solar sector needs strong local $R \& D$ and manufacturing to bring down costs over the long term. The Jawaharlal Nehru National Solar Mission (JNNSM) intends to introduce incentives for facilitating local manufacturing and R\&D. The loss in electricity distribution is important and needs to be addressed at substantial investment [24]. Small hydropower and biomass also face significant supply chain and industry development challenges. Because of limited and inconsistent market demand, small hydropower producers face significant capacity constraints and lacks standardization, which can cut costs significantly.

Moreover, we suggest that the Small and Medium-Sized Enterprises (SMEs) will be the key players in the deployment of sustainable energy technology and in providing services that support both industry and consumers. Supportive regulatory/ fiscal frameworks and financial support mechanisms are needed in all RE programs for enterprises experiencing capital constraints and difficulties in making it from the early business-planning stages through to operations and commercial sustainability [29].

Overall, the achievement and success of the RE development will depend to a large extent on the effectiveness with which government policy is developed and applied in relation to competing resource demands and policy in regards to barriers to development. There is a need for sustainable and active energy policies, which must be constituted by long- and short-term financial instruments [20].

\section{References}

[1] Nisar A, Monroy CR. A review of the potential of renewable energy sources for the state of Jammu and Kashmir (India). Energy Policy 2011;39:6667-71.

[2] Kelly G. History and potential of renewable energy development in New Zealand. Renewable and Sustainable Energy Reviews 2011:15:2501-9.

[3] International Energy Agency (IEA), World Energy Outlook 2007, Paris: International Energy Agency, Available at: <http://www.iea.org/textbase/ nppdf/free/2007/weo_2007.pdf $>$. [Last accessed on 15.03.2012].

[4] World Bank, South Asia Energy Unit - Sustainable Development Unit, Unleasing the Potential of Renewable Energy in India, (2010).

[5] Ministry of New and Renewable Energy (MNRE), Figures of estimated Renewable Energy Potential, Achievement as of December 31, (2009).

[6] United Nations, Framework Convention on Climate Change, Available at: $\langle$ http://unfccc.int/essential_background/glossary/items/3666.php\#C 〉. [accessed on 15.03.2012]

[7] Ministry of Power, Government of India, Available at: 〈http://powermin.nic. in $>$ ). [Last accessed on 15.03.2012].

[8] Liming $\mathbf{H}$. Financing rural renewable energy: a comparison between China and India. Renewable and Sustainable Energy Reviews 2009;13:1096-103.

[9] Directorate of Economics and Statistics, Government of India, Available at: $\langle$ http://dacnet.nic.in/eands/Land Use Statistics-2000/4.1.pdf 〉. [Last accessed on 15.06.2011].

[10] Ministry of New and Renewable Energy (MNRE), Renewable energy in India: Vision, Progress and Strategy. Ministry of new and renewable energy, Govt. of India, New Delhi, (2011).
[11] The Energy and Resources Institute (TERI), TEDDY TERI Energy Data Directory and Yearbook (1998/99). Tata Energy Research Institute, New Delhi,1999.

[12] Jammu and Kashmir Energy Development Agency (JAKEDA), Solar power policy for J\&K '2010', Srinagar, India, 2009.

[13] Ramachandra TV, Jain R, Krishnadas G. Hotspots of solar potential in India. Renewable and Sustainable Energy Reviews 2011:15:3178-86.

[14] United Nations (UN), Map of Jammu and Kashmir, Available at: 〈http:// www.un.org/depts/Cartographic/map/profile/kashmir.pdf $\rangle$. [accessed on 15.03.2012].

[15] The Economist, Comparing Indian states and territories with countries - An Indian Summary, Available at: $\langle\mathrm{http}: / / \mathrm{w} w \mathrm{w}$. economist.com/content/indiansummary $>$. [accessed on 21.06.2011].

[16] Chandrasekhar V, Chandrasekharam D. Energy independence through CDM using geothermal resources: Indian scenario: Proceedings World Geothermal Congress, Bali, Indonesia (2010).

[17] Chandrasekhar V, Chandrasekharam D. Enhanced geothermal resources in NE Deccan Province. India Geothermal Research Council Transactions 2008: 71-5.

[18] Chandrasekharam D. Geothermal Energy Resources of India: Past and the Present. Proceedings World Geothermal Congress Antalya, Turkey (2005).

[19] See: 〈http://www.rg.is/news-111210.php〉. [accessed on 15.03.2012].

[20] Monroy CR, Segundo Hernandez CS. Strengthening financial innovation in energy supply projects for rural exploitations in developing countries. Renewable and Sustainable Energy Reviews 2008;12:1928-43.

[21] Renewable Energy Policy Network for the 21st Century, Renewables global status report 2006 update, Available at: 〈http://www.ren21.net/Portals/97/ documents/GSR/RE GSR 2006 Update.pdf $\rangle$. [accessed on 21.06.2011].

[22] Himanshu N, Singal SK, Varun ASharma. Small hydropower for sustainable energy development in India. Renewable and Sustainable Energy Reviews 2011;15:2021-7.

[23] Ministry of New and Renewable Energy (MNRE). Available at: <www.mnes. nic.in > . [accessed on 21.06.2011].

[24] The Institut Français des Relations Internationales (IFRI), Energy in India's Future: Insights Gouvernance Europeenne Et Goepolotique De L'Energie Tome 7,Paris, (2009).

[25] Indian Renewable Energy Development Agency (IREDA), Available at: $\langle$ http://www.ireda.gov.in/ $\rangle$. [accessed on 22.06.2011].

[26] Planning Commission of India, Available at: 〈http://planningcommission. gov.in/> [accessed on 05.07.2011].

[27] Newbery D.M. Power sector reform, Private Investment and Regional Cooperation, SAARC Business Leaders Conclave, South Asia Regional Integration and Growth (2006)

[28] Jammu and Kashmir State Power Development Corporation (JKSPDC), Jammu and Kashmir State Electricity Regulatory Commission for determination of Generic Tariff for procurement of power from wind energy generators in the State of Jammu and Kashmir. Srinagar, India (2010)

[29] United Nations Energy Program (UNEP), Public Finance Mechanisms To Catalyze Sustainable Energy Sector Growth, (2005) Available online at: $\langle$ http://www.unep.fr/energy/activities/sefi/pdf/SEFI_PublicFinanceReport. pdf $\rangle$. [Last accessed 12/03/2012].

[30] Faaij A. Modern biomass conversion technologies. Mitigation and Adaptation Strategies for Global Change 2006;11:343-75.

[31] Saxena RC, Adhikari DK, Goyal HB. Biomass-based energy fuel through biochemical routes: a review. Renewable and Sustainable Energy Reviews 2009;13:167-78.

[32] Rittmann BE. Opportunities for renewable bioenergy using micro organisms. Biotechnology and Bioengineering 2008;100:203-12.

[33] Chandrasekharam D, Chandrasekhar V. Geothermal resources in India: Possibilities for direct use in the Himalayas in Proceedings " UNU-GTP and TBLRREM-TBGMED Workshop for Decision Makers on Direct Heating Use of Geothermal Resources in Asia", Tianjin, China, (2008).

[34] World Bank, The Indus Water Treaty 1960, Available at: <http://sitere sources.worldbank.org/INTSOUTHASIA/Resources/223497-1105737253588/ IndusWatersTreaty 1960.pdf $>$. [Accessed on 10.03.2012]

[35] Internal Revenue Service (IRS), Yearly average currency exchange rates, Available at: <http://www.irs.gov/businesses/small/international/article/ 0$, id $=206089,00 . h t m l\rangle$. [accessed on 15.03.2012]

[36] Abdul Azeez KK, Harinarayana T. Magnetotelluric evidence of potential geothermal resource in Puga, Ladakh, NW Himalaya. Current Science 2007;93:323-9.

[37] See: 〈http://www.panaxgeothemal.com.au/projects-intemational-india-puga. html $>$. [Last accessed 15.04.2012]. 